\title{
Semi-isostatic densification of heat-treated radiata pine
}

\author{
M. J. Boonstra · J. Blomberg
}

Received: 13 October 2006/Published online: 30 May 2007

(C) Springer-Verlag 2007

\begin{abstract}
Semi-isostatic densification is a useful method to increase the density and to improve the mechanical properties of fast-grown softwood species like radiata pine. A major disadvantage of this method is the almost complete recovery of the original dimensions when densified wood is exposed to moisture. Heat treatment improves the dimensional stability of wood and might be a useful method to prevent this shape-recovery after densification. However, no or only a limited effect on the shape-recovery was found when densified radiata pine was exposed to moisture.
\end{abstract}

\section{Introduction}

Radiata pine is a fast grown softwood species with a worldwide production in commercial forestry plantations (about 25 million hectares). It is characterized by wide growth rings $(1-2 \mathrm{~cm})$, a relatively low density $\left(400-500 \mathrm{~kg} / \mathrm{m}^{3}\right)$ and it contains a high percentage of juvenile wood since it is harvested at an age of less than 25 years. Several modification methods, such as chemical and compressive treatments, have been developed to increase the density of softwood species like radiata pine in order to improve the mechanical properties (strength and stiffness).

\footnotetext{
M. J. Boonstra ( $₫)$

Plato International BV, PO Box 2159, 6802 CD Arnhem, The Netherlands

e-mail: M.Boonstra@PlatoWood.nl

J. Blomberg

Dalarna University, 78188 Borlange, Sweden

J. Blomberg

Luleå University of Technology, 93187 Skelleftea, Sweden
} 
Impregnating the void volume of wood with bulking chemicals (e.g. monomers, polymers, resins, waxes) is a method which has been developed since the 1960s (Stamm 1964; Meyer 1984). Another method to increase the density of wood is compression in the transverse directions (Kollmann et al. 1975). A major disadvantage of this method is the recovery of the original dimensions when densified wood is exposed to moisture (swelling). This swelling is mainly due to cell wall bulking and especially cell-shape recovery (Blomberg et al. 2006). Heat treatment appears to have a positive effect on the dimensional stability of densified wood as described in several studies (Hsu et al. 1988; Inoue et al 1993, 1996; Dwianto et al. 1996; Ito et al. 1998; Navi and Girardet 2000; Rowell et al. 2002; Wolcott and Shutler 2003; Heger et al. 2004; Kamke 2006). This study was performed to investigate the effect of a two-stage heat treatment method under relatively mild conditions $\left(<200^{\circ} \mathrm{C}\right)$ on the recovery of densified radiata pine when exposed to moisture. Originally, this method was developed to improve the durability and dimensional stability of fast-grown and non-durable wood species (Boonstra et al. 1998, 2006a).

\section{Experimental}

\section{Materials}

Radiata pine boards (Pinus radiata D. Don.) were used for heat treatment and densification. Cross sections of the boards had a thickness of $30 \mathrm{~mm}$ and a width of $150 \mathrm{~mm}$. The length of the boards was approximately $3.0 \mathrm{~m}$. The boards were tangentially sawn. The moisture content of the boards was approximately 14-16\% prior to treatment.

\section{Heat treatment and densification}

The heat treatment was performed in two separate heat treatment stages and a drying stage in between. In the first stage of the heat treatment, the timber was treated in an aqueous environment at superatmospheric pressure $(0.8 \mathrm{MPa})$, a so called hydro-thermolysis treatment. This was done in a 6001 pilot plant at a treatment temperature of 165 or $185^{\circ} \mathrm{C}$ (30 min effective treatment time). The specimens were then dried in a $1 \mathrm{~m}^{3}$ (net) kiln, using a conventional drying process at $50-60^{\circ} \mathrm{C}$. After drying, the wood specimens were heat treated again for the second stage, now under dry and atmospheric pressure conditions, a so called "curing" treatment $\left(180^{\circ} \mathrm{C}, 6 \mathrm{~h}\right)$. During this stage superheated steam or nitrogen gas was used as a sheltering gas to exclude oxygen. The curing stage was performed in a special curing kiln or in a press (with dimensions of approximately $1 \times 2 \mathrm{~m}^{2}$ ). In the last case the length of the boards was reduced to $2 \mathrm{~m}$ before curing and six boards were treated in one curing charge. A static pressure of $10 \mathrm{MPa}$ was applied during curing to compress the boards and the treatment temperature varied between 160 and $190^{\circ} \mathrm{C}(4 \mathrm{~h})$. These boards were not used for semi-isostatically densification. 
Untreated, hydro-thermolysed and fully treated radiata pine boards were used for semi-isostatic densification (in duplicate). Untreated and treated boards with a thickness of $25 \mathrm{~mm}$, a width of $140 \mathrm{~mm}$ and a length of approximately $1.5 \mathrm{~m}$ were prepared (planed) before densification. The moisture content of the untreated, hydro-thermolysed and fully treated radiata pine boards was respectively 8.3, 8.5 and $7.0 \%$ before densification. The treated and untreated boards were semiisostatically compressed (at $20^{\circ} \mathrm{C}$ ) according to the CaLignum process (Lindhe and Castwall 1997) in a Quintus press to a pressure of approximately $140 \mathrm{MPa}$, which was reached after $2 \mathrm{~min}$. The pressure is mediated through a rubber membrane backed with oil. This enables weaker (low density) wood to be more compressed than harder structures (high density) such as knots. After the pressing period, the pressure was immediately released to atmospheric pressure. The boards were placed in the Quintus press with their pith sides towards the press table.

After densification, the hydro-thermolysed radiata pine boards were heat-treated again in a kiln according to the curing process as described above.

\section{Property testing}

Before and after densification the dimensions of the treated and untreated boards were measured using a sliding calliper (accuracy $0.03 \mathrm{~mm}$, repeatability $0.01 \mathrm{~mm}$ ). After densification the thickness was measured at three positions: on the left side $\left(H_{1}\right)$, on the right side $\left(\mathrm{H}_{2}\right)$ and in the middle $\left(\mathrm{H}_{3}\right)$ of the test boards. Furthermore, the maximum $\left(H_{\max }\right)$ and minimum $\left(H_{\min }\right)$ thickness of the densified test boards were measured. The width was measured on the topside $\left(W_{1}\right)$ and bottom side $\left(W_{2}\right)$ of the test boards.

Densified specimens (cross section $10 \times 10 \mathrm{~mm}^{2}$; length $30 \mathrm{~mm}$ ) were prepared (Fig. 1) and used to determine the swelling by measuring the dimensions of the specimens before and after soaking in water $\left(20^{\circ} \mathrm{C}\right)$ for $24 \mathrm{~h}$. A drop of soap was added to the water to avoid the influence of surface tension. After soaking, the densified specimens were oven dried for $24 \mathrm{~h}$ at $102 \pm 2{ }^{\circ} \mathrm{C}$ and the dimensions were again measured. The specimens were weighed under each test condition. Three replicates per board were used for this test.

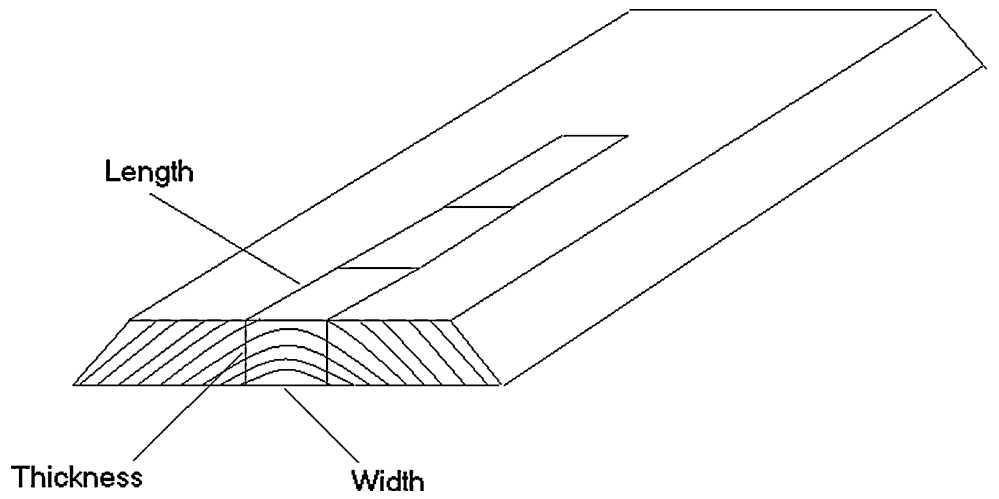

Fig. 1 Schematic overview of specimen preparation 
Densified specimen (thickness $10 \mathrm{~mm}$, width $30 \mathrm{~mm}$, length $30 \mathrm{~mm}$ ) were prepared (Fig. 1) and conditioned at $65 \%$ relative humidity (RH) for hygroscopicity testing. The specimens were then conditioned at $95 \% \mathrm{RH}$ (above a saturated potassium nitrate solution at $20^{\circ} \mathrm{C}$ ) or at $98 \% \mathrm{RH}$ (above water at $20^{\circ} \mathrm{C}$ ) until equilibrium moisture content (EMC) was reached. Subsequently, the specimens were oven dried $\left(24 \mathrm{~h}\right.$ at $\left.102 \pm 2{ }^{\circ} \mathrm{C}\right)$. Dimensions and weight of the specimens were measured before and after hygroscopicity testing. Three replicates per board were used for this test.

The Brinell hardness of densified specimens was determined according to EN 1534 (2000) using an indenting ball with a diameter of $10 \mathrm{~mm}$ that was forced to the tangential surface $(1 \mathrm{kN})$ for $30 \mathrm{~s}$. The indentation was measured by image processing on a picture with a magnification of $30 \times$. The diameter of the indentation was measured in four directions and the mean diameter was used to calculate the Brinell hardness.

\section{Results}

Densification of heat-treated radiata pine boards revealed small surface cracks parallel to the grain. Densification of knots in the fibre direction revealed more resistance and some raised areas of the wood surface around knots were noticed. During planing these raisings were removed without difficulty. However, very hard densified knots could damage the knives of planing machines and/or make them blunt more easily giving marks (e.g. stripes) on the wood surface. Knives made of flexible metal are therefore recommended instead of hard steel.

The dimensions of the specimens after densification are shown in Table 1 . The thickness of the boards was clearly decreased (47-56\%) whereas the width was slightly increased (4-7\%). This resulted in a reduction of the total volume by 45 to $55 \%$ and the density increased by 82 to $123 \%$ after densification (Table 2).

Water absorption, moisture content, swelling and shrinkage (tangential, radial, longitudinal and volumetric) of densified specimens during water soaking and EMC test are shown in Tables 3, 4, respectively. During the soaking test, water absorption of 88 and $99 \%$ was found for untreated and treated radiata pine, respectively. This is far above the fibre saturation point which means occurrence of free water in the cell lumina. Swelling of densified specimens in radial direction was 49 and $57 \%$ for untreated and treated radiata pine, respectively, indicating shape-recovery. Swelling

Table 1 Thickness and width of heat-treated and untreated radiata pine boards after semi-isostatic densification (thermolysis $165^{\circ} \mathrm{C}, 30 \mathrm{~min}$; curing $180^{\circ} \mathrm{C}, 6 \mathrm{~h}$ )

\begin{tabular}{|c|c|c|c|c|c|c|c|c|c|}
\hline \multirow[t]{2}{*}{ Radiata pine } & \multicolumn{6}{|c|}{ Thickness (mm) } & \multicolumn{3}{|c|}{ Width (mm) } \\
\hline & $H_{\max }$ & $H_{\min }$ & $H_{1}$ & $\mathrm{H}_{2}$ & $H_{3}$ & $H_{\text {mean }}$ & $W_{1}$ & $W_{2}$ & $W_{\text {mean }}$ \\
\hline Untreated & 14.4 & 12.2 & 14.4 & 12.9 & 12.3 & 13.2 & 148.9 & 150.0 & 149.5 \\
\hline Hydro-thermolysed & 11.3 & 10.2 & 11.2 & 10.2 & 11.3 & 10.8 & 142.4 & 148.1 & 145.3 \\
\hline Fully treated & 13.7 & 11.2 & 12.3 & 12.6 & 11.9 & 12.3 & 143.1 & 148.3 & 145.7 \\
\hline
\end{tabular}


Table 2 Volume decrease and increase in density of treated and untreated radiata pine after semiisostatic densification (thermolysis $165^{\circ} \mathrm{C}, 30 \mathrm{~min}$; curing $180^{\circ} \mathrm{C}, 6 \mathrm{~h}$ )

\begin{tabular}{llc}
\hline Radiata pine densified & $\begin{array}{l}\text { Volume decrease in percent } \\
\text { of the original volume }(\%)\end{array}$ & Increase in density (\%) \\
\hline Untreated & 45.1 & 82.1 \\
Hydro-thermolysed & 55.1 & 122.7 \\
Fully treated & 48.7 & 94.9 \\
\hline
\end{tabular}

Table 3 Water absorption, swelling, shrinkage, and moisture content (MC) of semi-isostatically densified radiata pine specimens during the soaking test (treatment conditions: thermolysis $165^{\circ} \mathrm{C}$, $30 \mathrm{~min}$; curing $180^{\circ} \mathrm{C}, 6 \mathrm{~h}$ )

\begin{tabular}{|c|c|c|c|c|c|c|c|c|c|c|c|}
\hline \multirow[t]{2}{*}{$\begin{array}{l}\text { Radiata pine } \\
\text { Densified }\end{array}$} & \multicolumn{4}{|c|}{ Swelling (\%) after soaking } & \multicolumn{4}{|c|}{$\begin{array}{l}\text { Shrinkage }(\%) \text { after oven } \\
\text { drying }\end{array}$} & \multicolumn{2}{|c|}{$\mathrm{MC}(\%)$} & \multirow[t]{2}{*}{$\begin{array}{l}\text { Absorption } \\
(\%)\end{array}$} \\
\hline & $\operatorname{Rad}$ & Tang & Long & Volume & $\operatorname{Rad}$ & Tang & Long & Volume & Start & Wet & \\
\hline Untreated & 49.4 & 0.3 & 0.2 & 50.2 & 10.5 & 4.7 & -0.1 & 14.6 & 11.9 & 110.8 & 88.4 \\
\hline Fully treated $1^{\mathrm{a}}$ & 57.2 & 5.8 & 0.2 & 66.7 & 25.8 & 5.2 & 0.2 & 29.8 & 8.7 & 116.5 & 99.2 \\
\hline Fully treated $2^{\mathrm{b}}$ & 40.5 & 7.2 & 0.1 & 50.7 & 31.0 & 8.4 & 0.3 & 37.0 & 9.1 & 90.3 & 74.3 \\
\hline
\end{tabular}

\footnotetext{
${ }^{a}$ The specimens were compressed after the two-stage heat treatment

b The specimens were compressed after the hydro-thermolysis stage and subsequently treated by the curing stage
}

Table 4 Water absorption, swelling and shrinkage, and moisture content (MC) of semi-isostatically densified radiata pine specimens during the hygroscopicity test (treatment conditions: thermolysis $165^{\circ} \mathrm{C}$, $30 \mathrm{~min}$; curing $180^{\circ} \mathrm{C}, 6 \mathrm{~h}$ )

\begin{tabular}{|c|c|c|c|c|c|c|c|c|c|c|c|}
\hline \multirow[t]{2}{*}{$\begin{array}{l}\text { Radiata pine } \\
\text { Densified }\end{array}$} & \multicolumn{4}{|c|}{$\begin{array}{l}\text { Swelling from } 65 \text { to } 95 \% \\
\text { RH }(\%)\end{array}$} & \multicolumn{4}{|c|}{$\begin{array}{l}\text { Shrinkage from } 95 \% \mathrm{RH} \text { to } \\
\text { oven dry }(\%)\end{array}$} & \multicolumn{2}{|c|}{$\mathrm{MC}(\%)$} & \multirow[t]{2}{*}{$\begin{array}{l}\text { Absorption } \\
(\%)\end{array}$} \\
\hline & $\operatorname{Rad}$ & Tang & Long & Volume & $\operatorname{Rad}$ & Tang & Long & Volume & Start & Wet & \\
\hline Untreated & 33.0 & 2.0 & 0.3 & 36.0 & 15.8 & 4.0 & 0.3 & 19.5 & 11.9 & 25.8 & 12.4 \\
\hline Fully treated $1^{\mathrm{a}}$ & 39.0 & 4.3 & 0.2 & 45.3 & - & - & - & - & 6.2 & 15.5 & 8.8 \\
\hline Fully treated $2^{\mathrm{b}}$ & 27.4 & 5.0 & 0.0 & 33.8 & 21.8 & 6.0 & 0.0 & 26.4 & 4.9 & 15.7 & 10.3 \\
\hline
\end{tabular}

\footnotetext{
a The specimens were compressed after the two-stage heat treatment

b The specimens were compressed after the hydro-thermolysis stage and subsequently treated by the curing stage
}

of densified radiata pine specimens after conditioning at $95 \%$ relative humidity (RH) was also rather high, although at a lower degree than after the water-soaking test (Table 4). The swelling of the radiata pine specimens which were densified before the curing stage appeared to be lower than for the untreated specimens and the specimens densified after the curing stage (Tables 3, 4).

The best results (=lowest swelling) were obtained with radiata pine specimens which were compressed during the curing stage (Table 5), although a swelling of 
Table 5 Moisture content and swelling of densified radiata pine specimens during the hygroscopicity test (treatment conditions: thermolysis $185^{\circ} \mathrm{C}, 30 \mathrm{~min}$; curing $160-190^{\circ} \mathrm{C}, 4 \mathrm{~h}$ including compression at $10 \mathrm{MPa})$

\begin{tabular}{llll}
\hline Curing temperature & \multicolumn{2}{l}{ Swelling from 65 to $98 \% \mathrm{RH}(\%)$} & MC at 98\% RH (\%) \\
\cline { 2 - 3 } & Rad & Tang & \\
\hline R. pine densified & & & \\
$160^{\circ} \mathrm{C}$ & 26.5 & 3.1 & 21.4 \\
$170^{\circ} \mathrm{C}$ & 26.0 & 3.6 & 21.6 \\
$180^{\circ} \mathrm{C}$ & 21.8 & 3.5 & 17.2 \\
$190^{\circ} \mathrm{C}$ & 20.0 & 3.6 & 17.3 \\
\hline
\end{tabular}

\footnotetext{
a The radiata pine specimens were compressed $(10 \mathrm{MPa})$ during the curing stage
}

$20-26 \%$ in radial direction still indicates a clear shape-recovery. An increase of the curing temperature to $190^{\circ} \mathrm{C}$ appeared to reduce the swelling and thus the shaperecovery.

In order to get an impression of the hygroscopicity and dimensional stability of non-densified radiata pine, the shrinkage (from saturated to oven dry) and EMC (at 65 and $98 \% \mathrm{RH}$ ) of treated and untreated radiata pine are shown in Table 6. The specimens showed a clear reduction of the shrinkage (radial and tangential) and EMC (especially at $98 \% \mathrm{RH}$ ) after heat treatment indicating an improvement of the dimensional stability.

Oven drying of the saturated specimens resulted in shrinkage in radial direction which was much higher for densified specimens than for non-densified specimens (Tables 3,6). The shrinkage of heat-treated densified radiata pine was higher than for untreated densified wood (Tables 3,4). The radiata pine specimens densified before the curing stage revealed the highest shrinkage.

The Brinell hardness of untreated radiata pine was increased by $271 \%$ after densification (Table 7). Heat treatment appeared to affect the Brinell hardness of densified radiata pine since it is lower than for the untreated wood. However, because the density of heat-treated radiata pine is lower after densification, a lower Brinell hardness was expected. Highest Brinell hardness was found for hydrothermolysed radiata pine, but these specimens also showed the highest density (Table 7).

Table 6 Shrinkage (from saturated to oven dry) and EMC (at 65\% and 98\% RH) of treated and untreated radiata pine, without densification (treatment conditions: thermolysis $165^{\circ} \mathrm{C}, 30 \mathrm{~min}$; curing $180^{\circ} \mathrm{C}, 6 \mathrm{~h}$ )

\begin{tabular}{llllllll}
\hline Radiata pine Non-densified & \multicolumn{2}{l}{ Shrinkage from saturated to oven dry (\%) } & & \multicolumn{2}{l}{ EMC (\%) } \\
\cline { 2 - 3 } & Rad & Tang & Long & & $65 \%$ RH & $98 \%$ RH \\
\hline Untreated & 4.3 & 7.9 & 0.39 & & 12.0 & 25.9 \\
Fully treated & 2.8 & 4.3 & 0.23 & & 6.7 & 17.2 \\
\hline
\end{tabular}


Table 7 Density and Brinell hardness of semi-isostatically densified and non-densified radiata pine specimens (at $20^{\circ} \mathrm{C}, 65 \% \mathrm{RH}$ )

\begin{tabular}{llc}
\hline Radiata pine & Density $\left(10^{3} \mathrm{~kg} / \mathrm{m}^{3}\right)$ & Hardness $\left(\mathrm{N} / \mathrm{mm}^{2}\right)$ \\
\hline Densified & & \\
Untreated & 1.049 & 71.4 \\
Hydro-thermolysed & 1.100 & 109.9 \\
Fully treated & 0.969 & 65.7 \\
Non-densified & & 19.2 \\
$\quad$ Untreated & 0.489 & \\
\hline
\end{tabular}

\section{Discussion}

Resistance against densification depends on the compressive strength in the transverse direction. A semi-isostatic pressure of $140 \mathrm{MPa}$ was apparently high enough to compress the radiata pine boards and to obtain a significant increase of the density (about 100\%). Since the effect of heat treatment on the compressive strength perpendicular to the grain is rather limited, no or only a limited effect on densification was expected (Boonstra et al. 2007). The difference between fully treated and untreated radiata pine was indeed rather small, although treated wood appeared to be more compressed than untreated wood (Table 2). Remarkable is the densification of hydro-thermolysed radiata pine which resulted in a higher volume loss and subsequently in a larger increase of the density than for untreated or fully treated wood. This can be due to differences in compression during densification and/or differences in elastic springback (immediate/delayed) after densification.

There are several chemical and physical factors which could affect densification (compression and/or springback) of heat-treated wood. According to Blomberg et al. (2006) semi-isostatic densification results in a compression of the tracheids which were flattened and irregularly shaped, and deformation of the rays into a curly and tilted shape. They have also noticed shearing and cracking of the cell walls, especially in the first formed earlywood. The effect of heat treatment on the anatomical structure of wood is rather limited (Boonstra et al. 2006b). Heat treatment of radiata pine appears to cause some damage to parenchyma cells in the rays and epithelial cells around resin canals. Rays contribute to the compressive strength in radial direction (Kennedy 1968; Ellis and Steiner 2002) and damages of the rays might improve this compression since less resistance of the rays during pressing is expected.

Chemical changes of the main wood components (cellulose, hemicelluloses and lignin) during heat treatment could also have an effect on the densification of heattreated wood (Tjeerdsma et al. 1998, Tjeerdsma and Militz 2005, Boonstra and Tjeerdsma 2006). Although, the strength properties of the cell wall are closely related to the occurrence of cellulose fibrils and microfibrils, the hemicelluloseslignin matrix is also thought to play an important role in wood strength properties (Winandy and Rowell 1984; LeVan et al. 1990; Sweet and Winandy 1999; Winandy and Lebow 2001; Boonstra et al. 2007). Degradation and/or modification of hemicelluloses which mainly occurs during the hydro-thermolysis stage might have 
a negative effect on the compressive strength of wood. Another phenomenon which occurs during the hydro-thermolysis stage is softening of the cell wall due to plastification of the main wood components, especially lignin and the remaining hemicelluloses (Goring 1963; Hillis and Rozsa 1978, 1985; Shiraishi 2001). Softening of the cell wall is probably still noticeable after the hydro-thermolysis stage facilitating the compression of the cells during densification. However, it is expected that this plastification effect should be higher when the boards were heated during pressing. The curing treatment stage, which is characterized by an increase of the relative proportion of crystalline cellulose and an increased cross linking of the lignin polymer network, changes the properties of the cell wall making it more brittle and less susceptible to elastic deformation. This provides a positive contribution to the compressive strength of the cell wall restricting compression of the cells during densification. This might explain the lower degree of compression of fully treated radiata pine compared to hydro-thermolysis treated wood (Table 2).

Although, heat treatment of non-densified radiata pine resulted in a reduction of the shrinkage and swelling behaviour (Table 6), it did not provide a fixation effect for densified wood (Fig. 2). The swelling of heat-treated densified radiata pine during the water-soaking test is even higher than for untreated densified radiata pine (Table 3). This could be due to the higher degree of compression of fully treated radiata pine compared to untreated wood (Table 2). The same tendency was noticed in the EMC test. Although, the swelling of densified wood after conditioning at a relative humidity of $95 \%$ was slightly lower than after the soaking test, a clear shape-recovery was visible with untreated radiata pine performing better than fully treated radiata pine (Table 4). A hydro-thermolysis treatment is therefore not advisable as post-treatment of densified wood, since this treatment stage is performed in a saturated environment and shape-recovery is then expected.

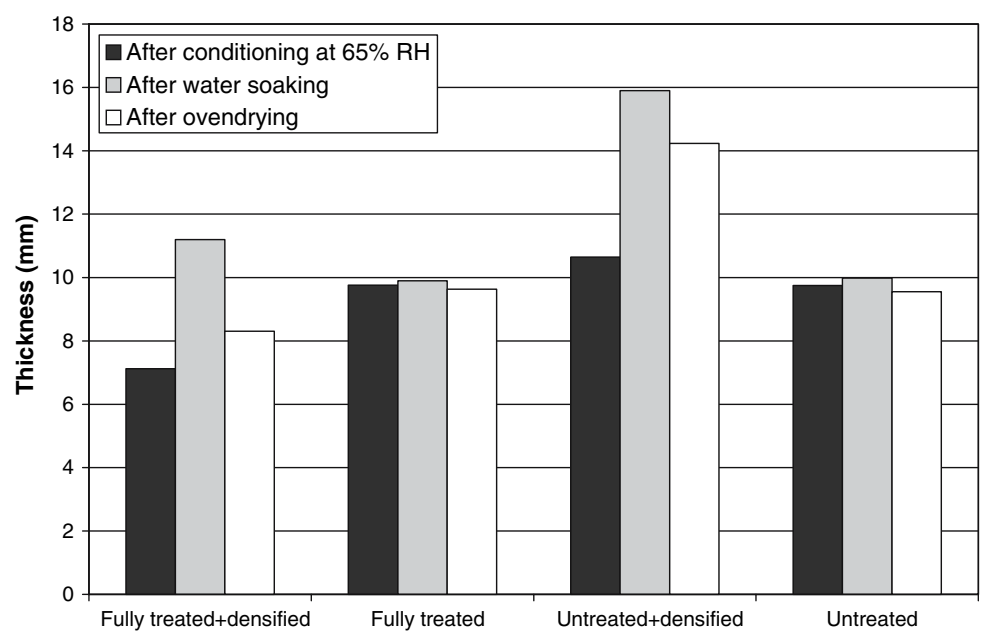

Fig. 2 Thickness (radial direction) of treated and untreated radiata pine specimens after conditioning at $65 \%$ relative humidity $\left(20^{\circ} \mathrm{C}\right)$, after water soaking $\left(20^{\circ} \mathrm{C}\right)$, and after oven drying $\left(102^{\circ} \mathrm{C}, 24 \mathrm{~h}\right)$ 
Densification before the curing treatment stage of radiata pine appeared to have some effect on the shape-recovery. The swelling of the specimens after water soaking or conditioning at $95 \% \mathrm{RH}$ is lower than for untreated densified radiata pine. This was remarkable because both the degree of compression and density of the specimens were higher than for the untreated wood, but this did not result in a higher shape-recovery. However, there is no question that shape-recovery still occurred when the densified specimens were exposed to moisture.

It was expected that a better fixation could be obtained when the curing and pressing stage were combined (heat treatment during pressing). Plastizication of the remaining hemicelluloses and/or the lignin polymer network, and condensation reactions within the lignin polymer network might result in a fixation of the cell wall to a more permanent structure which is less susceptible to moisture. However, a combination of curing and compression (at $10 \mathrm{MPa}$ ) did not prevent recovery of the dimensions since a significant swelling still occurred when the specimens were exposed to moisture (Table 5). Increasing the curing temperature to $190^{\circ} \mathrm{C}$ did reduce the swelling of the densified radiata pine specimens but a significant recovery of the dimensions still occurred.

Application of a higher pressure during densification might result in an increased cracking of the cell wall limiting or preventing swelling of the cell wall when exposed to moisture. This, however, might also disturb the cohesion between cells affecting the mechanical properties (Blomberg et al. 2005).

Remarkable is the shrinkage of densified specimen from saturated (swollen) to oven dry conditions which is significantly higher than for non-densified wood indicating a (partly) recovery of the cell-shape of densified wood (Fig. 2). Heat treatment appeared to have an effect on this recovery since the shrinkage of treated densified wood is higher than for untreated wood. The specimens which were compressed before the curing stage showed the highest shrinkage. This observation is again an indication that heat treatment affects the densification of wood, but it is not completely clear how it affects densification.

\section{Conclusion}

Semi-isostatic densification is a useful method to increase the density and to improve the mechanical properties of fast-grown softwood species like radiata pine. Although heat treatment improves the dimensional stability of wood, no or only a limited effect was found on the recovery of the dimensions when densified radiata pine was exposed to moisture.

Acknowledgments The authors wish to thank Orsa Träutveckling $\mathrm{AB}$ for doing parts of the experimental work.

\section{References}

Blomberg J, Persson B, Blomberg A (2005) Effects of semi-isostatical densification of wood on the variation in strength properties with density. Wood Sci Technol 39:339-350 
Blomberg J, Persson B, Bexell U (2006) Effects of semi-isostatic densification on anatomy and cell-shape recovery on soaking. Holzforschung 60:322-331

Boonstra MJ, Tjeerdsma BF (2006) Chemical analysis of heat treated softwoods. Holz Roh-Werkst 64:204-211

Boonstra MJ, Tjeerdsma BF, Groeneveld HAC (1998) Thermal modification of non-durable wood species. Part 1. The Plato technology: thermal modification of wood. International research group on wood preservation, document no. IRG/WP 98-40123

Boonstra MJ, Van Acker J, Kegel E, Stevens M (2006a) Optimisation of a two-stage heat treatment process. Durability aspects. Wood Sci Technol 41:31-57

Boonstra MJ, Rijsdijk JF, Sander C, Kegel E, Tjeerdsma BF, Militz H, Van Acker J, Stevens M (2006b) Physical aspects of heat treated wood. Part 1. Softwoods. Maderas: Ciencia y Tecnologia 8(3):193208

Boonstra MJ, Van Acker J, Tjeerdsma BF, Kegel E (2007) Strength properties of thermally modified softwoods and its relation to polymeric structural wood constituents. Ann For Sci (in press)

Dwianto W, Inoue M, Tanaka F, Norimoto M (1996) The permanent fixation of compressive deformation in wood by heat treatment. In: Proceedings from the 3rd Pacific Rim Bio-based composites symposium, Kyoto, Japan

Ellis S, Steiner P (2002) The behaviour of five wood species in compression. IAWA J 23:201-211

EN 1534 (2000) Wood and parquet flooring - determination of resistance to indentation (Brinell) - test method. European standard

Goring DAI (1963) Thermal softening of lignin, hemicelluloses and cellulose. Pulp Pap Mag Can 64:T517-T-527

Heger F, Groux M, Girardet F, Welzbacher C, Rapp AO, Navi P (2004) Mechanical and durability performance of THM-densified wood. Final Workshop COST Action E22 Environmental optimisation of wood protection, Lisbon, pp 22-23

Hillis WE, Rozsa AN (1978) The softening temperatures of wood. Holzforschung 32:69-73

Hillis WE, Rozsa AN (1985) High temperature and chemical effects on wood stability. Part 2. The effect of heat on the softening of radiata pine. Wood Sci Technol 19:57-66

Hsu WE, Schwald W, Schwald J, Shields A (1988) Chemical and physical changes required for producing dimensionally stable wood-based composites. Part 1: Steam pre-treatment. Wood Sci Technol 22:281-289

Inoue M, Norimoto M, Tanahashi M, Rowell RM (1993) Steam or heat fixation of compressed wood. Wood Fiber Sci 25(3):224-235

Inoue M, Sekino N, Morooka T, Norimoto M (1996) Dimensional stabilization of wood composites by steaming I. Fixation of compressed wood by pre-steaming. In: proceedings from the 3th Pacific Rim Bio-based composites symposium, Kyoto, Japan

Ito Y, Tanahashi M, Shigematsu M, Shinoda Y, Ohta C (1998) Compressive-molding of wood by highpressure steam-treatment. Part 1 . Development of compressively molded squares from thinnings. Holzforschung 52(2):211-216

Kamke FA (2006) Densified radiata pine for structural composites. Maderas. Ciencia y technologia 8(2):83-92

Kennedy RW (1968) Wood in transverse compression. For Prod J 18:36-40

Kollmann FP, Kuenzi EW, Stamm AJ (1975) Principles of wood science and technology. Vol. II Wood based materials. Springer, Heidelberg, pp 139-149

LeVan SL, Ross RJ, Winandy JE (1990) Effects of fire retardant chemicals on bending properties of wood at elevated temperatures. Research paper. FPL-RP-498

Lindhe C, Castwall L (1997) Process for producing hard elements of wood. U.S. Patent No. 5,678,618

Meyer JA (1984) Wood-polymer materials. In: Rowell (ed) The chemistry of solid wood. American Chemical Society, Washington, DC, pp 257-290

Navi P, Girardet F (2000) Effects of thermo-hydro-mechanical treatment on the structure and properties of wood. Holzforschung 54(3):287-293

Rowell R, Lange S, McSweeny J, Davis M (2002) Modification of wood fiber using steam. In: Proceedings from the 6th Pacific Rim Bio-based composites symposium \& workshop on the chemical modification of cellulisics, Portland

Shiraishi N (2001) Wood plasticization. In: Hon, Shiraishi (eds) Wood and cellulosic chemistry. Marcel Dekker Inc., New York, pp 655-700

Stamm AJ (1964) Dimensional stabilization and Densified wood. In: Wood and cellulose science. The Ronald Press Company, USA, pp 312-358 
Sweet MS, Winandy JE (1999) The influence of degree of polymerisation (DP) of cellulose and hemicellulose on the strength loss of fire-retardant-treated wood. Holzforschung 53(3):311-317

Tjeerdsma BF, Militz H (2005) Chemical changes in hydrothermal treated wood: FTIR analysis of combined hydrothermal and dry heat-treated wood. Holz Roh-Werkst 63:102-111

Tjeerdsma BF, Boonstra M, Pizzi A, Tekely P, Militz H (1998) Characterisation of thermally modified wood: molecular reasons for wood performance improvement. Holz Roh-Werkst 56:149-153

Winandy JE, Rowell RM (1984) The chemistry of wood strength. In: Rowell (eds) The Chemistry of solid wood. American Chemical Society, Washington, DC, pp 211-256

Winandy JE, Lebow PK (2001) Modelling strength loss in wood by chemical composition. Part I. An individual component model for southern pine. Wood Fiber Sci 33(2):239-254

Wolcott MP, Shutler EL (2003) Temperature and moisture influence on compression-recovery behavior of wood. Wood Fiber Sci 35(4):540-551 